\title{
An Analysis of Long-Term Outcomes in Patients with Locally Advanced Cervical Cancer Treated by Chemoradiation with Reference to the Additional Performance of Hysterectomy Due to Emergency Vaginal Bleeding or Hemorrhage.
}

\section{Research}

Keywords:

Posted Date: December 2nd, 2020

DOI: https://doi.org/10.21203/rs.3.rs-94554/v2

License: (c) (i) This work is licensed under a Creative Commons Attribution 4.0 International License. Read Full License 


\section{Abstract}

The authors have requested that this preprint be withdrawn due to erroneous posting.

\section{Full Text}

The authors have withdrawn this preprint from Research Square. 